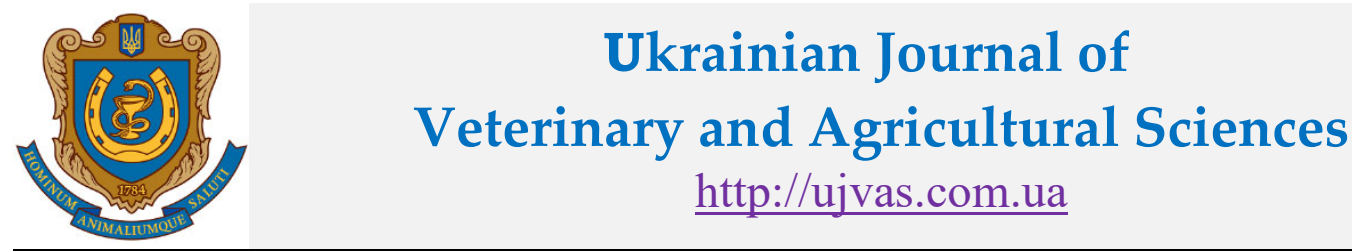

Stepan Gzhytskyi National University of Veterinary Medicine and Biotechnologies Lviv

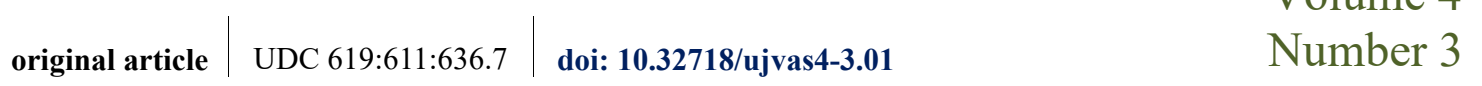

\title{
Effects of implant Suprelorin on cytological changes of vaginal epithelial cells in female dogs $(4.7 \mathrm{mg}$ deslorelin)
}

\author{
T. V. Holumbiyovska, V. Y. Stefanyk, T. P. Basarab
}

Stepan Gzhytskyi National University of Veterinary Medicine and Biotechnologies, Pekarska str., 50, Lviv, 79010, Ukraine

\begin{tabular}{l} 
Article info \\
Received 21.06.2021 \\
Received in revised form \\
26.07 .2021 \\
Accepted 27.07.2021 \\
\hline Correspondence author \\
Tetyana Holumbiyovska \\
Tel.: +38-093-154-46-72 \\
E-mail: holumbiyka2712@gmail.com \\
\hline 2021 Holumbiyovska T. et al. This \\
is an open-access article distributed \\
under the terms of the Creative \\
Commons Attribution License, \\
which permits unrestricted use, \\
distribution, and reproduction in any \\
medium, provided the original \\
author and source are credited.
\end{tabular}

(c) EY

\begin{abstract}
Diagnosis of the estrous cycle in female dogs is important in veterinary medicine. The estrous cycle is divided into the following stages: proestrus, estrus, diestrus, metestrus, and anestrus, which due to the action of hormones, replace one after another. This feature of the estrous cycle leads to some difficulties with reproduction. It is hard to obtain newborns because of prolonged anestrus. Vaginal cytology is a simple and available diagnostic method of the estrous cycle. It is based on the analysis of vaginal mucosa epithelial cells changes. This method is used to determine the time of mating and diagnose pathological conditions in the reproductive system of female dogs. There are various drugs in veterinary medicine for the correction of the estrous cycle in female dogs. We used implant Suprelorin ${ }^{\circledR}$ to estrus induction. There were described methods of estrus stimulation using a subcutaneous implant Suprelorin $(4.7 \mathrm{mg}$, deslorelin) and changes in vaginal epithelial cells using the vaginal cytology method. The study was performed on twelve $(n=12)$ adult female dogs in the anestrus stage. Implants were injected subcutaneously in the groin area and removed at the beginning of the estrus.
\end{abstract}

Keywords: ovulation, estrus, dog, stimulation of estrus, vaginal cytology, Suprelorin, deslorelin, infertility.
Contents

1. Introduction

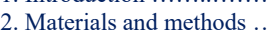

.

. Results and discussion

onclusions

............... 9

Citation:

Holumbiyovska, T. V., Stefanyk, V. Y., \& Basarab, T. P. (2021). Effects of implant Suprelorin on cytological changes of vaginal epithelial cells in female dogs (4.7 mg deslorelin). Ukrainian Journal of Veterinary and Agricultural Sciences, 4(3), 3-10.

\section{Introduction}

The estrous cycle is a complex neurohumoral process characterized by morphological and physiological changes in the reproductive system and the other organs. In the practice of veterinary medicine, various classifications of the estrous cycle have been introduced. According to Heape W. In 1901, the most common classification was proposed to divide it into four stages: proestrus, estrus, diestrus, and anestrus (Heape, 1900; Bielański \& Tischner, 1997).

The appearance of clinical signs of heat is usually observed in proestrus, and this is considered the initial of the estrous cycle. This stage lasts from three to twenty-five days (usually six to eleven), characterized by redness and swelling of the vulva with subsequent appearance of mucousbloody discharge. The time of onset of these clinical signs should be considered the first day of proestrus. During this stage, dogs show interest in female dogs, but they do not allow mating. These changes are caused by an increased level of estrogen in the blood synthesized in the follicles.
Under the influence of estradiol in female dogs also produces pheromones that attract males. The next stage of proestrus is estrus, which is characterized by swelling of the vulva and its softening, color change of the mucous membrane, and color of the discharge. It lasts from two to twenty-one days (usually from five to nine) (Nizanski et al., 2003; Van den Berghe et al., 2019). Changes in the behavior of the bitch during this period were usually observed. It allows males to the coitus. There was a determined decrease in estrogen and an increase in progesterone (Simpson et al., 1998; Nizanski et al., 2003; Kustritz, 2012). Also, the preovulatory release of luteinizing hormone from the pituitary gland was observed. Day of luteinizing hormone increase is considered the zero-day of the estrous cycle. A sharp increase in the concentration of the luteinizing hormone is a trigger of ovulation that occurs 40-50 hours after the peak of that hormone (Nizanski et al., 2003; Long, 2006). This is followed by luteinization of the follicle and its vascularization, leading to an increased concentration of progesterone and a decrease of estrogen (Concannon et al., 2018). 
Ovulation is the release of an egg from a follicle (Yablons'kyy \& Khomin, 2006). Ovulatory follicles mature from secondary to preovulatory during the proestrus. After the diameter of follicles reaches $4 \mathrm{~mm}$, granulosa cells increase the synthesis of estrogen. The main form of a female dog is estradiol $17-\beta$, which stimulates changes in the vaginal epithelium, diagnosed by vaginal cytology. In the estrus, luteinization of follicles was observed with the next progesterone synthesis. At the same time decrease in estrogen synthesis was observed (Kustritz, 2012). As mentioned above, luteinizing hormone is a key factor in ovulation.

Diestrus is the post-heat period when the dog is no longer able and susceptible to mating. At the beginning of this stage, a slight discharge could be observed (Kustritz, 2012). Diestrus can last from fifty-six to fifty-eight days in pregnant dogs and from sixty to one hundred days in nonpregnant (Nizanski et al., 2003). Another article reports that diestrus in pregnant female dogs lasts from sixty-two to sixty-four days and in non-pregnant from forty-nine to seventy-nine. At this stage, the progesterone level increases and then decreases depending on the growth and development of the corpus luteum. Progesterone is also synthesized by the placenta (Kustritz, 2012; Rosnina et al., 2017). Anestrus is considered the period from the day of parturition or decrease of progesterone below one $\mathrm{ng} / \mathrm{ml}$ in non-pregnant dogs and until the onset of proestrus (Nizanski et al., 2003; Feldman et al., 2014). The duration of this stage varies from four to twelve months. It is characterized by a decrease in the gonad's hormonal activity (Nizanski et al., 2003). Also, follicle development is minimized, corpus luteum could be identified but regresses and is not functional. Clinically, anestrus is characterized by a lack of discharge and pallor of the genitals' mucous membranes (Noakes, 2009).

Since the prolonged anestrus negatively impacts the fertilization frequency, estrus stimulation is economically justified (Walter et al., 2011). Determining the time of ovulation is a critical factor in animal reproduction (Concannon, 2011). Luteinizing hormone concentration is the most accurate diagnostic method for determining ovulation. The peak concentration of the luteinizing hormone is relatively short; monitoring of this hormone should be performed every day. This is problematic for owners due to logistical difficulties and is also quite costly. In most cases, veterinarians prefer to determine the concentration of progesterone, as well as the use of vaginal cytology (Kustritz, 2012).

Vaginal cytology is proposed as a fast, affordable, and cheap method of determining the stage of the estrous cycle of dogs, and also allows to neglect the determination of hormone concentrations, help determine the time of artificial or natural insemination, and determine the effect of estrogen on the reproductive organs of a dog (Sharma \& Sharma, 2016; England, 2016; Rosnina et al., 2017; Antonov, 2017; Meliou, 2018; Park et al., 2019).

Several types of cells are differentiated in a vaginal smear. According to most authors, basal, parabasal, intermediate, superficial, and non-nuclear cells have been microscopically observed. Changes in the ratio of these cells occur due to the action of sex hormones, including estrogen and progesterone. However, it was proposed to count the number of erythrocytes and leukocytes (Antonov, 2017; Arlt, 2018; Haji et al., 2018; Mason, 2018; Peña-Corona et al., 2019). In addition, with the help of vaginal cytology, it is possible to determine the pathological condition of the reproductive tract of the dog (Kim et al., 2018; Šiugždaite et al., 2018; Haji et al., 2018).

Our study aimed to determine changes in the epithelial cells of the vagina during the estrous cycle in dogs, which were applied implant Suprelorin ${ }^{\circledR}(4.7 \mathrm{mg}$, deslorelin).

\section{Materials and methods}

Studies were performed at the Department of Obstetrics, Gynecology, and Biotechnology of Animal Reproduction, named after G. V. Zvereva Stepan Gzhytskyi National University of Veterinary Medicine and Biotechnologies Lviv, and Canine Training Center of the State Border Guard Service of Ukraine military unit 2418. Twelve $(n=12)$ adult female dogs aged three to seven years were selected for the study. Four of the German Shepherd breed, two - Bernese Mountain Dog breed, and one Newfoundland, Moscow Watchdog, Labrador, Pomeranian Spitz, and two Yorkshire Terriers. In that animal, according to the anamnesis was not observed signs of proestrus and estrus for more than 90 days.

All animal manipulations were carried out following the European Convention for the Protection of Vertebrate Animals, used for Experimental and Scientific Purposes (Official Journal of the European Union L276/33, 2010).

Ovulation was stimulated by implant Suprelorin ${ }^{\circledR}$ (4.7 $\mathrm{mg}$ deslorelin). Deslorelin increases the synthesis of gonadotropin-releasing hormone, follicle-stimulating hormone, and luteinizing hormone by stimulating the anterior pituitary.

Implants were injected subcutaneously into the groin area. The day of implant placement was considered zero-day. The implant was removed on the ninth day. Infiltration anesthesia with $2 \%$ lidocaine solution was used for local anesthesia.

Collection of vaginal smears was performed on days 0 , $3,5,7,9$, and 14 days after implant injection.

The diagnosis was performed on the basic microscopic examination of vaginal smears (Nizanski et al., 2003). Samples collection were performed with a vaginal stick, preapplied with $0.9 \%$ sodium chloride solution. Obtained samples were applied on a slide by a circular motion of the vaginal stick. Staining was performed with "Leucodif 200". Light microscopy performed image registration using a microscope Leica DM-2500 (Switzerland) and a camera Leica DFC 450C and software Leica Application Suite Version 4.4. Basal and parabasal cells (were included in one group), intermediate, superficial. Cell differentiation was performed according to changes in the morphological structure of the cell - the ratio of cytoplasm to the nucleus of the cells and the presence of keratinization. Cell counting was performed with ImageJ software (National Institutes of Health, Bethesda, MD, USA).

Data were presented as mean $\pm \mathrm{SD}$ (standard deviation). A significance level was calculated with the Student's test. Statistical significance was assumed $\mathrm{P}<0.05$. Statistical analysis was performed with SPSS software (IBM, USA).

\section{Results and discussion}

\section{Results}

The purpose of implant administration of Suprelorin ${ }^{\circledR}$ (4.7 mg deslorelin) was to stimulation estrus. The day of implant insertion was considered - zero-day. According to 
the obtained results, proestrus in bitches was observed between the third and the seventh day. In seven dogs, it was observed on the fifth day, in four on the seventh, and in one on the third day from the date of implant placement.

Estrus in bitches was observed between the seventh and the fourteenth days. In four dogs, estrus was observed on the seventh day and in eight dogs - on the ninth day.

On the fifth day, there was observed bloody vaginal discharge and vulva swelling. Male dogs were interested in the female dogs, but coitus was not observed. Clear vaginal discharge and swollen vulva were observed on the ninth day.
Based on the results obtained, $81.25 \pm 4.35 \%$ of parabasal cells (fig. 1) were found. On the third day, the number of parabasal cells was $61.58 \pm 7.87 \%(\mathrm{P}<0.001)$. The number of parabasal cells statistically significantly decreased to $9.83 \pm 2.29 \%(\mathrm{P}<0.001)$. On the seventh day, there was a statistically significant decrease in the number of parabasal cells; it was $3.83 \pm 1.85 \%(\mathrm{P}<0.001)$. On the ninth day and on the fourteenth day, the lowest number of parabasal cells: $0.08 \pm 0.29 \%(\mathrm{P}<0.001)$ and $0.00 \pm 0.00 \%(\mathrm{P}<0.001)$ was observed.

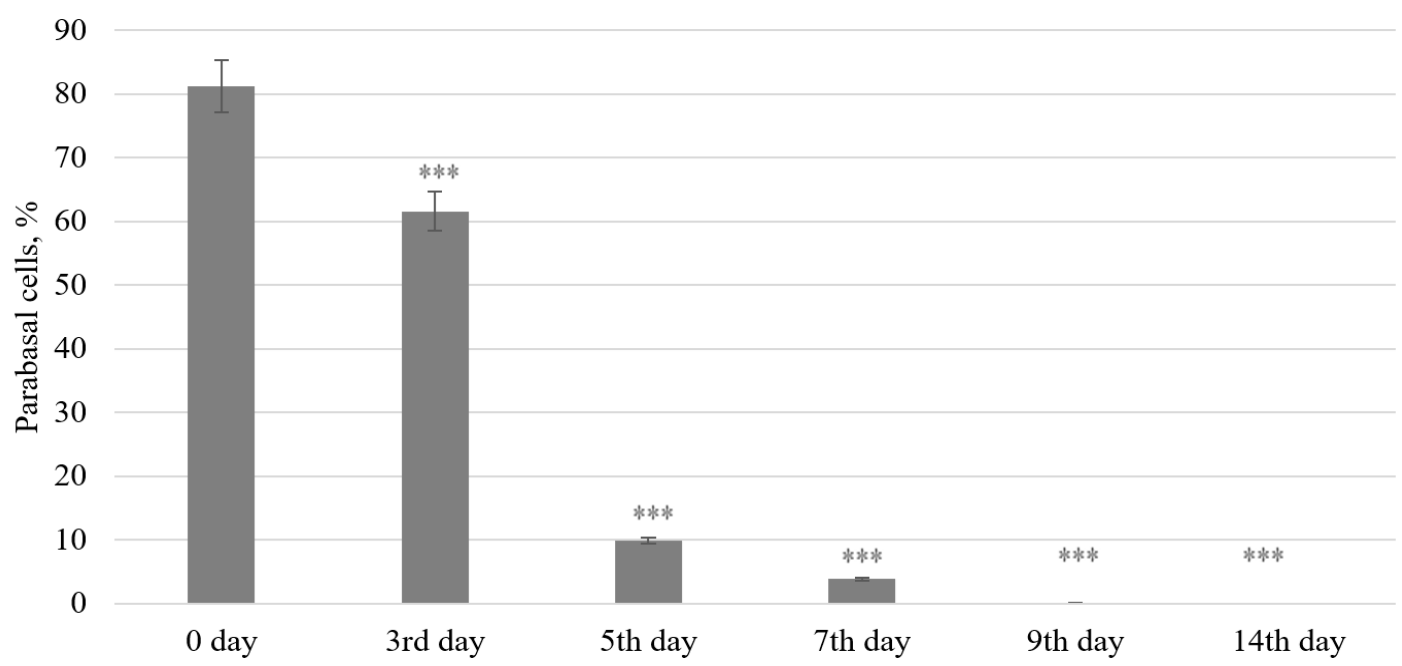

Fig. 1. Parabasal cells dynamics during the estrous cycle in the female dogs Notes: statistically significant compared to 0 days $* * *-\mathrm{P}<0.001$.

It was found (fig. 2) that on the zero-day, the number of intermediate cells was $8.17 \pm 2.76 \%$, while on the third day, it increased to $24.33 \pm 4.85 \%(\mathrm{P}<0.001)$. On the fifth day, the highest number of intermediate cells was found, $57.42 \pm 8.18 \%(\mathrm{P}<0.001)$. On the seventh day, the number of intermediate cells was $25.75 \pm 4.56 \%$ ( $\mathrm{P}<0.001)$. On the ninth day, number of intermediate cells was $1.17 \pm 2.25 \%$ $(\mathrm{P}<0.001)$ and on the fourteenth day $0.00 \pm 0.00 \%$ $(\mathrm{P}<0.001)$.

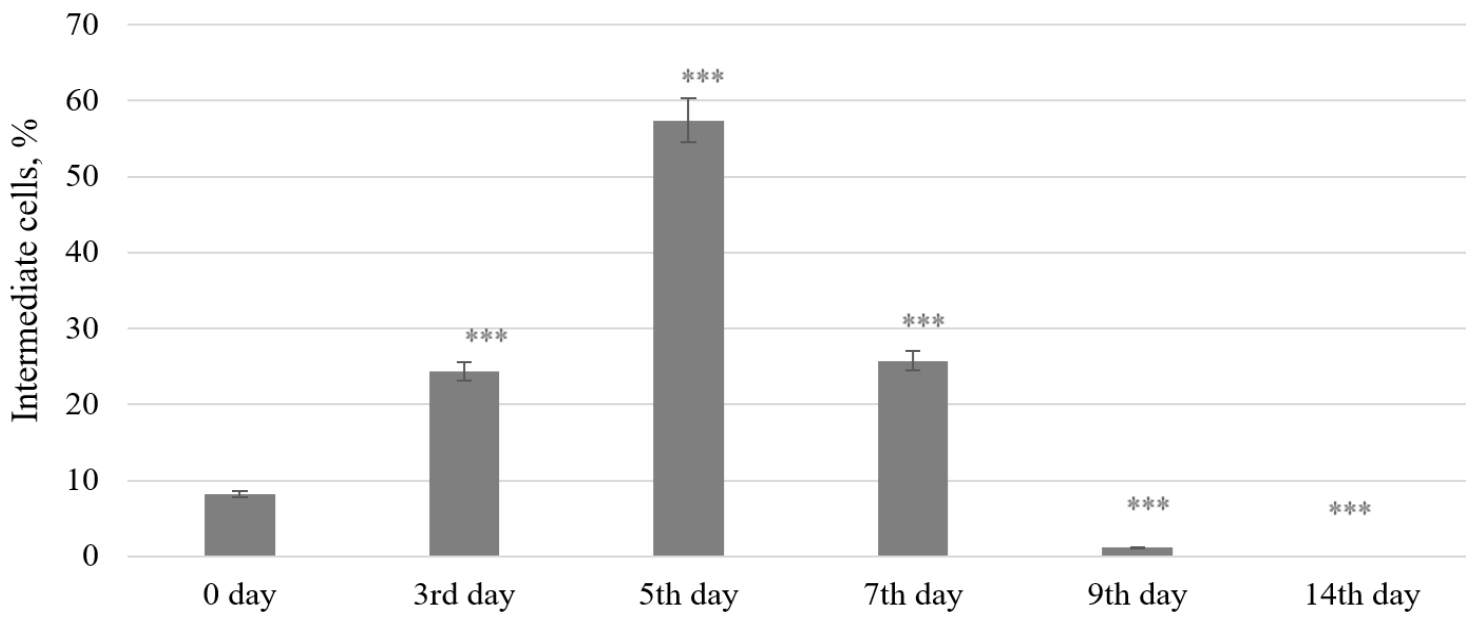

Fig. 2. Intermediate cells dynamics during the estrous cycle in the female dogs Notes: statistically significant compared to 0 days $* * *-\mathrm{P}<0.001$.

The results (fig. 3) show that the number of superficial cells was $2.25 \pm 1.14 \%$ on the zero-day. On the third day, it increased to $9.42 \pm 3.29 \%(\mathrm{P}<0.001)$. On the fifth day, the number of superficial cells increased to $26.83 \pm 7.6 \%$ $(\mathrm{P}<0.001)$. On the seventh day, the superficial cells in- creased to $58.75 \pm 4.99 \%(\mathrm{P}<0.001)$. The highest number of superficial cells was observed on the ninth day

$71.58 \pm 10.5 \%(\mathrm{P}<0.001)$. On the fourteenth day, the number of superficial cells was $20.42 \pm 2.97 \%(\mathrm{P}<0.001)$. 


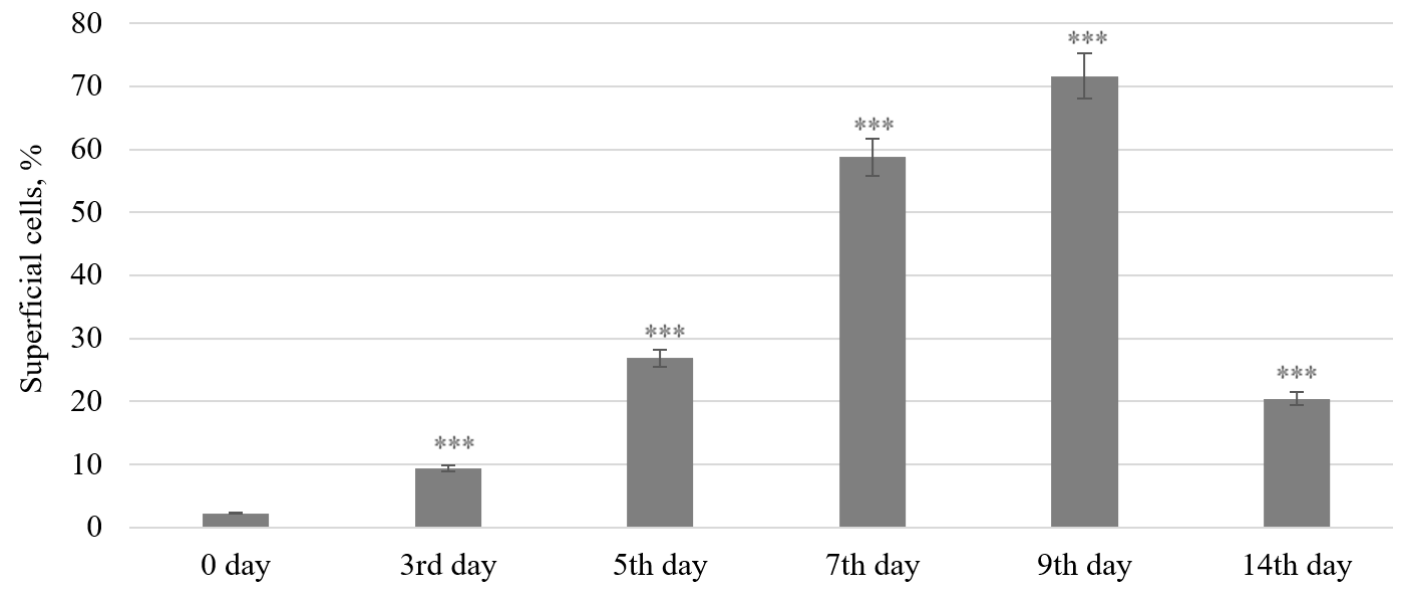

Fig. 3. Superficial cells dynamics during the estrous cycle in the female dogs Notes: statistically significant compared to 0 day $* * *-\mathrm{P}<0.001$.

Based on the results obtained (fig. 4), it was found $8.33 \pm 2.71 \%$ of non-nuclear cells. On the third day number of these cells decreased to $4.67 \pm 2.46 \%$ ( $\mathrm{P}<0.01)$. On the fifth day, the number of non-nuclear cells was $5.92 \pm 1.62 \%$ $(\mathrm{P}<0.05)$. On the seventh day, the number of cells in- creased to $11.67 \pm 2.23 \%(\mathrm{P}<0.01)$. On the ninth day, it increased to $27.17 \pm 11.67 \%(\mathrm{P}<0.001)$. On the fourteenth day, the number of non-nuclear cells was $79.58 \pm 2.97 \%$ $(\mathrm{P}<0.001)$.

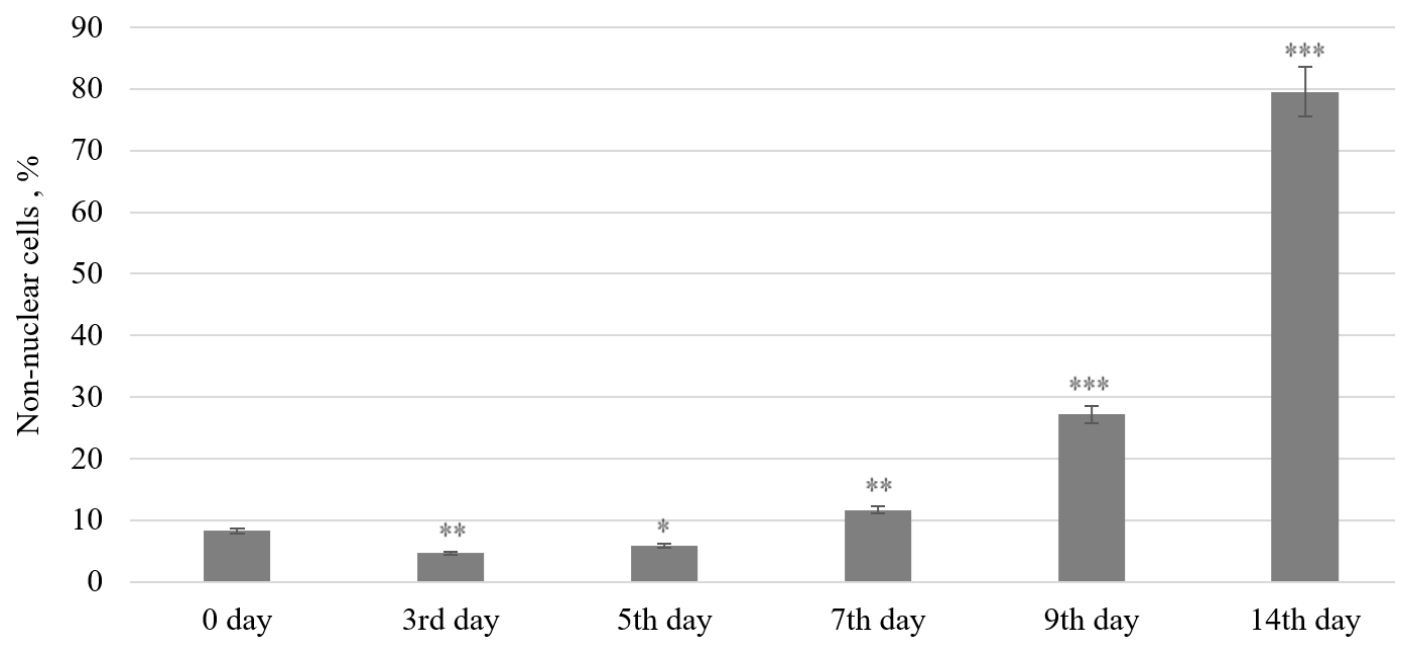

Fig. 4. Non-nuclear cells dynamics during the estrous cycle in the female dogs Notes: statistically significant compared to 0 day $*-\mathrm{P}<0.05 ; * *-\mathrm{P}<0.01 ; * * *-\mathrm{P}<0.001$

\section{Discussion}

Dogs are monoestrous animals. Seven months are considered a normal estrous cycle. In most dogs, ovulation occurs twice a year (Walter et al., 2011). Pathology of the dog reproductive tract is frequently diagnosed. It is characterized by prolonged anestrus or lack of heat (Holumbiovska \& Stefanyk, 2018). Under such conditions, estrus induction is recommended (Concannon, 1989; Johnston et al., 2001; Walter et al., 2011).

Methods of ovulation stimulation were described in the literature, require regular administration of drugs from 4 to 30 days (bromocriptine or cabergoline). Several studies describe the administration of cabergoline at dose $5 \mathrm{IU} / \mathrm{kg}$, per os during 21 days or equine chorionic gonadotropin at dose $20 \mathrm{IU} / \mathrm{kg}$, per os subcutaneously for five days with the next administration of human chorionic gonadotropin at a dose of 500 IU per animal (De Gier et al., 2008; Fontaine et al., 2011; Jurczak et al., 2016).

These methods are inconvenient because they are timeconsuming. The preference of the Suprelorin $(4.7 \mathrm{mg}$ deslorelin) is the provision of a stable and gradual release of the active substance. A synthetic analog of gonadotropinreleasing hormone $(\mathrm{GnRH})$ - deslorelin, which is the active substance of the implant, provides a pulsating release of a hormone that has an effect similar to the action of natural GnRH (Kutzler, 2005; Fontaine et al., 2011). Deslorelin is GnRH agonist that stimulates estrus in adult dogs (Maenhoudt et al., 2018).

Neuroendocrine regulation of the estrous cycle occurs under the action of the hypothalamus and pituitary gland, and ovaries. Follicle maturation occurs under the influence of gonadotropic hormones - luteinizing (LH) and folliclestimulating hormone (FSH), synthesized by the anterior pituitary gland. It is typical for the initial stage of the estrous cycle - proestrus. Secretion of LH and FSH is regulated by $\mathrm{GnRH}$, is synthesized by the hypothalamus. An increase of FSH is important for follicles development and as a result, secretion of estrogen. Increasing concentrations of estrogen were observed in the proestrus (Van Haaften et al., 1994; Simpson et al., 1998; Nizanski et al., 2003). Christie D. W. and Bell E. T., reported that the concentration of estrogen reaches a peak during the last days of proestrus or on the 
first day of estrus (Christie \& Bell, 1971). In dogs, after estrogen increasing, a peak concentration of LH was observed (Lindsay, 1983). Usually, this happens 24-48 hours after the onset of estrogen peak (Jeffcoate, 1993; Concannon, 1993; Onlcin et al., 1995).

There is an inverse correlation between the concentration of estrogen and progesterone in the blood plasma. As the concentration of estrogen in the blood decreases, an increase in progesterone is observed. That happens because of changes in Graaf follicles after ovulation. After morphological changes in follicles, a decrease of estrogen and an increase of progesterone secretion could be observed. The beginning of a preovulatory increase in the concentration of progesterone in the blood occurs simultaneously and/or the beginning of the peak of LH (Phemister et al., 1973;
Concannon et al., 1975). This initial increase in progesterone secretion coincides with a decrease in estrogen secretion. Since progesterone stimulates a decrease in estrogen and estrogen receptors in target cells (Resko et al., 1976; West et al., 1976; Concannon et al., 1977). Ovulation occurs 24-96 hours after the peak concentration of LH (Wildt et al., 1978).

For our studies, epithelial cells were separated according to the described method. Cells were separated into four groups: parabasal, intermediate, superficial cells with a nucleus and anuclear. To differentiate cells, the criteria were: size, shape, the correlation between the nucleus and cytoplasm (Christie \& Bell, 1971; Christie et al., 1972; Linde \& Karlsson, 1984).

100

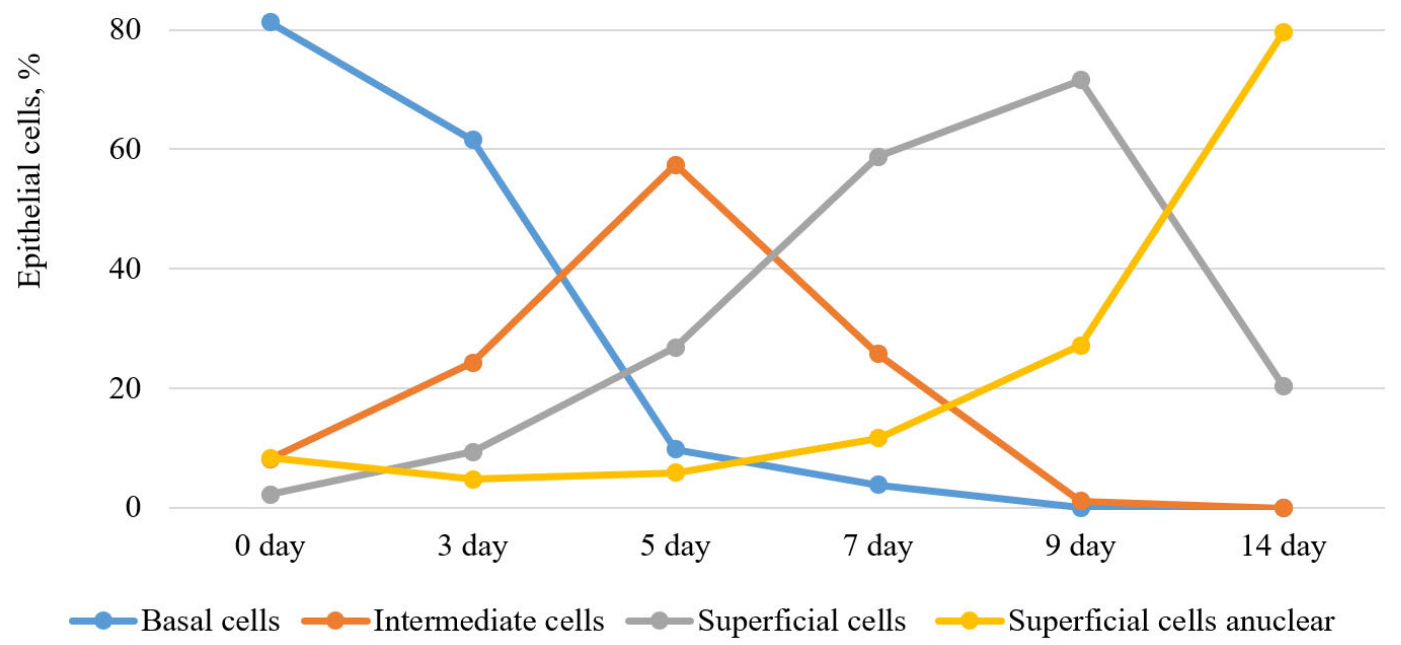

Fig. 5. Epithelium cells changes after implementation of implant

On the zero and third days (fig. 5), basal and parabasal cells were mostly observed. On the third and fifth days, a decrease in parabasal cells and an increase of intermediate cells were observed. Intermediate epithelial cells - were larger than parabasal cells, rounded contours, with large nuclei. On the fifth and seventh days, a decrease of parabasal cells and the appearance of a large number of intermediate cells were observed. Also, on the seventh day, the appearance of superficial cells with a nucleus was noted. Changes that were described occurred as a result of the influence of estradiol 17- $\beta$. Estrogen leads to cell proliferation and increases the number of epithelium layers. An increase of estrogen concentration stimulates cell division in the basal layer of the vaginal epithelium, with the next decrease of the hormonal influence of the multilayered epithelium. Estrogens impact the vascularization of the mucous layer accompanied by edema and the appearance of erythrocytes in vaginal cytology. The appearance of vaginal bleeding is due to the increased blood flow in the uterus and its capillary permeability. At the time of heat, clinical signs appearance (bloody discharge, redness, and swelling of the vulva), males were interested in females. It happens under the action of estrogens and pheromones (Nizanski et al., 2003; Smoliak, 2019). Subsequently, in the late proestrus, the number of epithelial cells containing the nucleus decreased.
Changes of the vagina epithelial cells after administration implant Suprelorin can be found on figure 5 and figure 6.

Similar studies were in Belgium, with implant $(2.1 \mathrm{mg}$ deslorelin Ovuplant ${ }^{\circledR}$ ) for stimulation of ovulation, where proestrus was observed 6 days after application (Kutzler et al., 2002). Other authors used a (4.7 mg deslorelin, Suprelorin () obtained similar to us results, they observed bloody dis-charge in dogs on day 6 after application (Volkmann et al., 2006; Volkmann et al., 2006; Kutzler et al., 2009). In addition, there are data about dogs of different breeds, proestrus was observed on the 4 day, other studies show that proestrus was observed the 5 days after application of implant (Walter et al., 2011; Fontaine \& Fontbonne, 2011; Fontaine et al., 2011).

There was a significant increase (fig. 5) of superficial epithelial cells (decreased on the fourteenth day), and superficial anuclear cells (keratinized epithelium), decreased number of intermediate and parabasal cells in the vaginal cytology were observed between the seventh and fourteenth days. Estrogens induce cell proliferation within the next exfoliating from the basement membrane. As a result, epithelial cells in the vaginal discharge could be found (Schutte, 1967; Basarab et al., 2020). Superficial epitheliocytes could be more than $90 \%$ of all epithelial cells and at the beginning of ovulation, more than $80 \%$ superficial anuclear epitheliocytes. 


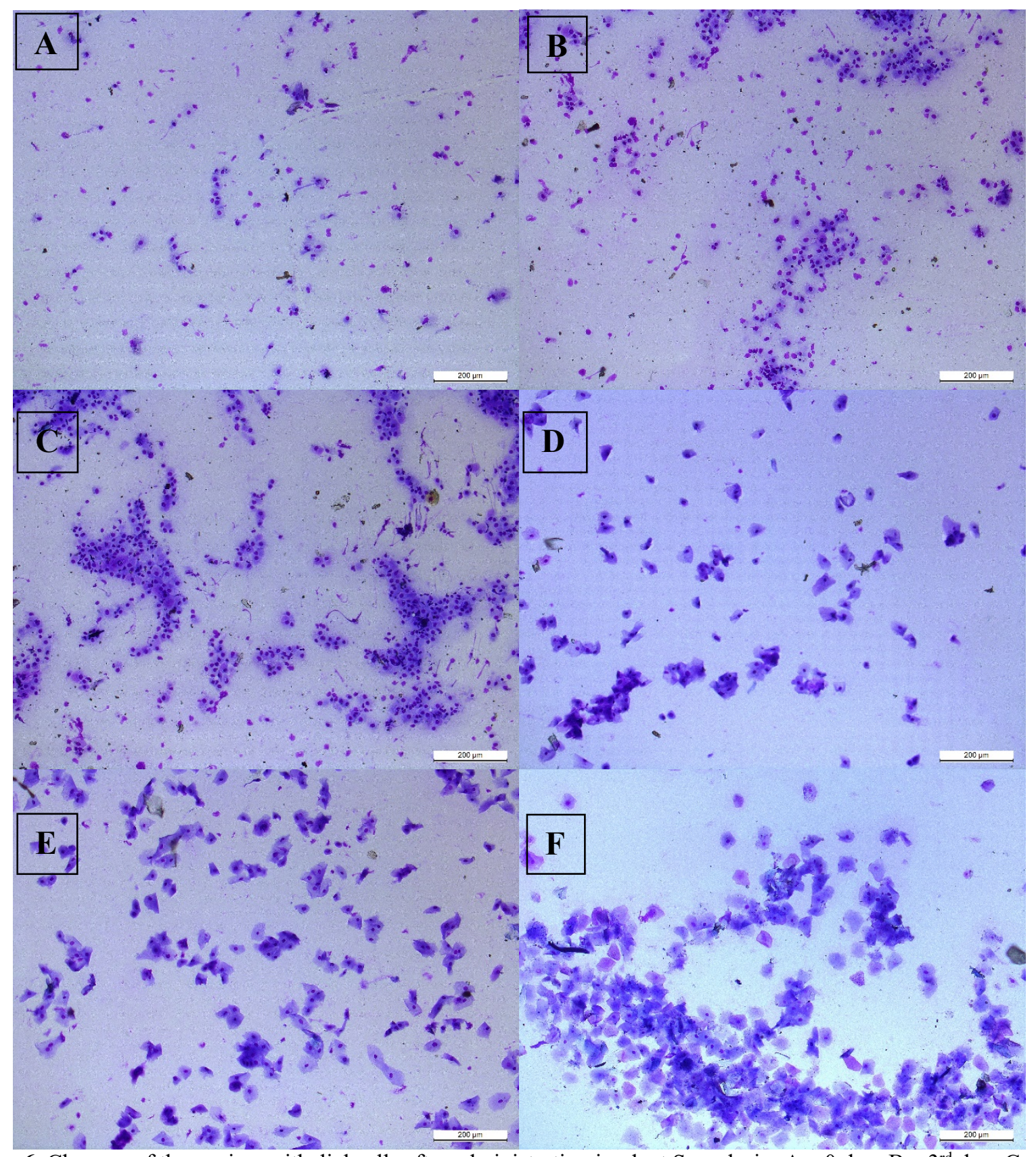

Fig. 6. Changes of the vagina epithelial cells after administration implant Suprelorin: $\mathrm{A}-0$ day; $\mathrm{B}-3^{\text {rd }}$ day; $\mathrm{C}-5^{\text {th }}$ day; $\mathrm{D}-7^{\text {th }}$ day; $\mathrm{E}-9^{\text {th }}$ day, $\mathrm{F}-14^{\text {th }}$ day

There were degenerative changes in the nuclei of superficial cells: chromatin condensation, pyknosis, which in turn leads to their karyorrhexis or more often to karyolysis. At the later term of heat, there were more pronounced degenerative changes of the nuclei in most epithelium cells (Schutte, 1967; Nizanski et al., 2003). In a large number of exfoliated cells, the structure of the nucleus was not clear or was not visualized. Types of cells detected in cytological smears expressed stages of keratinization and degeneration of the nuclei, with next cell death of vaginal mucosa (Schutte, 1967; Goodman, 1992; Nizanski et al., 2003).

The peak of keratinization of cells coincides with the beginning increase of progesterone concentration. However, there were no described clinical signs at the initial stages that are typical for the beginning of the fertile period. That stage usually comes in a few days (Simpson et al., 1998; Nizanski et al., 2003). Estrus is characterized by swelling of the vulva, a change in the color of the mucous membrane, and the discharge color. During this period, there are chang- es in the behavior of the dog. It already shows signs of tolerance for the male, allows mating.

The results show that estrus was observed on the seventh and ninth day after implant application. There are data about implant Ovuplant ${ }^{\circledR}(2.1 \mathrm{mg}$, deslorelin), where estrus was observed at the $10.5 \pm 2.9$ days (Kutzler et al., 2002; Volkmann et al., 2006; Kutzler et al., 2009). Others reported that ovulation was observed at $11.8 \pm 2.1$ days after implantation. Using implant Ovuplant ${ }^{\circledR}(2.1 \mathrm{mg}$ deslorelin), ovulation was observed in $62 \%-100 \%$. It depends on the time of implant introduction, with better results during anestrus than diestrus. Also, there were re-ported, ovulation in $87.5 \%$ of bitches when the implant was introduced in late anestrus (200-590 days after the previous estrus) if the implant was introduced in early anestrus (80-160 days after the previous estrus) ovulation was observed only in $62.5 \%$ (Nizanski et al., 2003; Walter et al., 2011; Fontaine \& Fontbonne, 2011; Fontaine et al., 2011). 


\section{Conclusions}

In conclusion, implant Suprelorin (4.7 $\mathrm{mg}$ deslorelin) stimulated estrus (heat) in dogs in the anestrus stage. Implant stimulated changes in the hormonal status of the dogs. Vaginal cytology is a simple and informative diagnostic method condition of the reproductive system. Dynamics of the epithelium, observed by vaginal cytology, allows understanding the changes in the vaginal mucosa under the influence of a synthetic analog of GnRH.

\section{Conflict of interest}

The authors declare that there is no conflict of interest.

\section{References}

Antonov, A. L. (2017). Application of exfoliative vaginal cytology in clinical canine reproduction-a review. Bulgarian Journal of Veterinary Medicine, 20(3), 193-203. doi: 10.15547/bjvm.997.

Arlt, S. (2018). Canine ovulation timing: A survey on methodology and an assessment on reliability of vaginal cytology. Reproduction in Domestic Animals, 53, 53-62. DOI: 10.1111/rda.13352.

Basarab, T. P., Stefanyk, V. Y., Koziorowski, M., Kozioł, K., \& Pilip, A. R. (2020). Estrogen and progesterone endometrial cell receptors in cows with subclinical endometritis. Scientific Messenger of $L N U$ of Veterinary Medicine and Biotechnologies. Series: Veterinary Sciences, 22(100), 141-150. doi: 10.32718/nvlvet10024.

Bielański, A., \& Tischner, M. (1997). Biotechnologia rozrodu zwierząt udomowionych, 144-145. URL: https://w.bibliotece.pl/ 2769468/Biotechnologia+rozrodu+zwierząt+udomowionych.

Christie, D. W., \& Bell, E. T. (1971). Endocrinology of the oestrous cycle in the bitch. Journal of Small Animal Practice, 12(7), 383-389. doi: 10.1111/j.1748-5827.1971.tb06245.x.

Christie, D. W., Bailey, J. B., \& Bell, E. T. (1972). Classification of cell types in vaginal smears during the canine oestrous cycle. British Veterinary Journal, 128(6), 301-310. doi: 10.1016/s0007-1935(17)36935-x.

Concannon, P. W. (1989). Induction of fertile oestrus in anoestrous dogs by constant infusion of GnRH agonist. Journal of reproduction and fertility. Supplement, 39, 149-160. URL: https://pubmed.ncbi.nlm.nih.gov/2695635.

Concannon, P. W. (1993). Biology of gonadotrophin secretion in adult and prepubertal female dogs. Journal of reproduction and fertility. Supplement, 47, 3-27. URL: https://pubmed.ncbi. nlm.nih.gov/8229941.

Concannon, P. W. (2011). Reproductive cycles of the domestic bitch. Animal reproduction science, 124(3-4), 200-210. doi: 10.1016/j.anireprosci.2010.08.028.

Concannon, P. W., Castracane, V. D., Temple, M., \& Montanez, A. (2018). Endocrine control of ovarian function in dogs and other carnivores. Animal Reproduction (AR), 6(1), 172-193. URL: HTTPS:// www.animal-reproduction.org/article/5b5a606ef7783717068b4766.

Concannon, P. W., Hansel, W., \& Visek, W. J. (1975). The ovarian cycle of the bitch: plasma estrogen, LH and progesterone. Biology of reproduction, 13(1), 112-121. doi: 10.1095/biolreprod13.1.112.

Concannon, P., Hansel, W., \& Mcentee, K. (1977). Changes in LH, progesterone and sexual behavior associated with preovulatory luteinization in the bitch. Biology of reproduction, 17(4), 604613. doi: 10.1095/biolreprod17.4.604.

De Gier, J., Beijerink, N. J., Kooistra, H. S., \& Okkens, A. C. (2008). Physiology of the canine anoestrus and methods for manipulation of its length. Reproduction in Domestic Animals, 43, 157-164. doi: 10.1111/j.1439-0531.2008.01156.x.

England, G. (2016). Canine reproduction: when to mate, pre-mate test and vaginal cytology, timing of mating and implications, how to advise the breeder? In BSAVA Congress Proceedings 2016 (pp. 124-125). BSAVA Library.
Feldman, E. C., Nelson, R. W., Reusch, C., \& Scott-Moncrieff, J. C. (2014). Canine and feline endocrinology-e-book. Elsevier health sciences.

Fontaine, E., \& Fontbonne, A. (2011). Clinical use of GnRH agonists in canine and feline species. Reproduction in domestic animals, 46(2), 344-353. doi: 10.1111/j.1439-0531.2010.01705.x.

Fontaine, E., Mir, F., Vannier, F., Albouy, M., \& Fontbonne, A. (2011). Use of anti-oestrogens and aromatase inhibitors to prevent heat induction in anoestrous bitches treated with deslorelin implants. In Reproduction in Domestic Animals (Vol. 46, pp. 105-105). Commerce Place, 350 Main St, Malden 02148, Ma USA: Wiley-Blackwell.

Fontaine, E., Mir, F., Vannier, F., Gérardin, A., Albouy, M., Navarro, C., \& Fontbonne, A. (2011). Induction of fertile oestrus in the bitch using Deslorelin, a GnRH agonist. Theriogenology, 76(8), 1561-1566. doi: 10.1016/j.theriogenology.2011.06.031.

Goodman, M. F. (1992). Canine ovulation timing. Problems in veterinary medicine, 4(3), 433-444.

Haji, M. M., Borpujari, D., Talukdar, D. J., Ahmed, F. A., Lalrintluanga, K., \& Sarma, K. (2018). Cystic endometrial hyperplasia-open pyometra complex in a female pug. Indian Journal of Animal Reproduction, 39(1), 63-65.

Haji, M., Ahmed, F. A., Lalrintluanga, K., Talukdar, D. J., Doley, P. J., Bahera, S. K., \& Sarma, K. (2018). The role of estrogen and progesterone hormone on vaginal cytology in bitch. Int $J$ Livest Res, 8(9), 241-247. doi: 10.5455/ijlr.20171117025427.

Heape, W. (1900). Memoirs: The "Sexual Season" of Mammals and the Relation of the "Pro-œstrum" to Menstruation. Journal of Cell Science, 2(173), 1-70. doi: 10.1242/JCS.s2-44.173.1.

Holumbiovska, T. V., \& Stefanyk, V. Y. (2018). Disorders of reproductive function in female dogs and methods of diagnostic. Scientific Messenger of LNU of Veterinary Medicine and Biotechnologies. Series: Veterinary Sciences, 20(83), 385-395. doi: $10.15421 /$ nvlvet8376.

Jeffcoate, I. A. (1993). Endocrinology of anoestrous bitches. Journal of reproduction and fertility. Supplement, 47, 69-76. URL: https://pubmed.ncbi.nlm.nih.gov/8229987.

Johnston, S. D., Root Kustritz, M. V., \& Olson, P. S. (2001). Canine and feline theriogenology. Saunders.

Jurczak, A., Domosławska, A., Bukowska, B., \& Janowski, T. (2016). Equine chorionic gonadotropin and human chorionic gonadotropin stimulation increase the number of luteinized follicles and the progesterone level compared with cabergoline stimulation anoestrus bitches. Reproduction in Domestic Animals, 51(4), 562-568. doi: 10.1111/rda.12720.

Kim, M. K., Yoon, H. Y., Lee, M. H., \& Kim, J. H. (2018). Canine pyometra associated with Bacillus species: a case report. Veterinární medicína, 63(3), 143-149. doi: 10.17221/36/2017VETMED.

Kustritz, M. V. R. (2012). Managing the reproductive cycle in the bitch. Veterinary Clinics: Small Animal Practice, 42(3), 423437. doi: 10.1016/j.cvsm.2012.01.012.

Kutzler, M. A. (2005). Induction and synchronization of estrus in dogs. Theriogenology, 64(3), 766-775. doi: 10.1016/j.theriogenology.2005.05.025.

Kutzler, M. A., Wheeler, R., Lamb, S., \& Volkmann, D. H. (2002). Deslorelin implant administration beneath the vulvar mucosa for the induction of synchronous estrus in bitches. In Proceedings of Third EVSSAR European Congress.

Kutzler, M., Lamb, S. V., \& Volkmann, D. (2009). Comparison between vestibular and subcutaneous insertion of deslorelin implants for oestrus induction in bitches. Reproduction in Domestic Animals, 44, 83-86. doi: 10.1111/j.1439-0531.2009.01384.x.

Linde, C., \& Karlsson, I. (1984). The correlation between the cytology of the vaginal smear and the time of ovulation in the bitch. Journal of Small Animal Practice, 25(2), 77-82. doi: 10.1111/j.1748-5827.1984.tb00449.x.

Lindsay, F. E. F. (1983). The normal endoscopic appearance of the caudal reproductive tract of the cyclic and non-cyclic bitch: post-uterine endoscopy. Journal of Small Animal Practice, 24(1), 1-15. doi: 10.1111/j.1748-5827.1983.tb00407.x. 
Long, S. (2006). Veterinary Genetics and reproductive physiology. Elsevier Health Sciences. URL: https://www.elsevier.com/books/veterinary-genetics-andreproductive-physiology/long/978-0-7506-8877-2.

Maenhoudt, C., Santos, N. R., \& Fontbonne, A. (2018). Manipulation of the estrous cycle of the bitch - what works... for now. Reproduction in Domestic Animals, 53, 44-52. doi: $10.1111 /$ rda. 13364 .

Mason, S. J. (2018). The current review of artificial insemination in dogs. Veterinary Clinics: Small Animal Practice, 48(4), 567-580. doi: 10.1016/j.cvsm.2018.02.005.

Meliou, E. V. (2018). Comparison of the cytobrush and cotton swab for vaginal cytology in dogs (Doctoral dissertation).

Nizanski, W., Dzimira, S., \& Twardon, J. (2003). Cytodiagnostyka w rozrodzie suk. Wydawnictwo Akademii Rolniczej, Wrocław.

Noakes, D. E. (2009). Arthur's Veterinary Reproduction and Obstetrics E-Book. Elsevier Health Sciences.

Onlcin, K., Verstegen, J., Silva, L. D. M., \& Concannon, P. (1995). Patterns of circulating prolactin, LH, and FSH during dopamine-agonist induced termination of anestrus in beagle dogs. In Biology of Reproduction, 52, 135-135.

Park, C. H., Yang, J. Y., \& Son, C. H. (2019). Application of Vaginal Cytology to the Prediction of Whelping Day in Small Pet Bitches. Journal of Veterinary Clinics, 36(1), 38-41. doi: 10.17555/jvc.2019.02.36.1.38.

Peña-Corona, S., León, P., Mendieta, E., Villanueva, M., Salame, A., Vargas, D., ... \& Villa-Godoy, A. (2019). Effect of a single application of coumestrol and/or dimethyl sulfoxide, on sex hormone levels and vaginal cytology of anestrus bitches. Veterinaria México, 6(1), 1-15. URL: https://www.medigraphic.com/cgi$\mathrm{bin} /$ new/resumenI.cgi?IDARTICULO $=86789$.

Phemister, R. D., Holst, P. A., Spano, J. S., \& Lloyd Hopwood, M. (1973). Time of ovulation in the beagle bitch. Biology of Reproduction, 8(1), 74-82. doi: 10.1093/biolreprod/8.1.74.

Resko, J. A., Boling, J. L., Brenner, R. M., \& Blandau, R. J. (1976). Sex steroids in reproductive tract tissues: regulation of estradiol concentrations by progesterone. Biology of reproduction, 15(2), 153-157. doi: 10.1095/biolreprod15.2.153.

Rosnina, S., Choong, Z., Wahid, H., Aidi, M., \& YAP, K. (2017). Correlation between Vaginal Cytology and Serum Progesterone in Sumatran Rhinoceros (Oicerorhinus sumatrensis). Theriogenology, 53(9), 1717-1728. URL: http://psasir.upm.edu.my/id/eprint/29959.

Schutte, A. P. (1967). Canine vaginal cytology-I technique and cytological morphology. Journal of Small Animal Practice, 8(6), 301-306. doi: 10.1111/j.1748-5827.1967.tb04554.x.

Sharma, M., \& Sharma, N. (2016). Vaginal cytology: An historical perspective on its diagnostic use. Adv. Anim. Vet. Sci, 4(6), 283288. URL: http://nexusacademicpublishers.com/table_contents detail/4/681/HTML

Simpson, G., England, G. C., \& Harvey, M. (1998). BSAVA manual of small animal reproduction and neonatology. British Small Animal Veterinary Association.
Šiugždaite, J., Zgirskienė, R. J., \& Šengaut, J. (2018). Vaginal microflora of healthy bitches during the different stages of the reproductive cycle and bitches with vaginitis. In 21st EVSSAR Congress „Reproduction and pediatrics in dogs, cats and small companion animals ": Venice, Italy, 22-23 June 2018: abstract book/European Veterinary Society for Small Animal Reproduction (EVSSAR); Editors: Sabine Schäfer-Some, George Mantziaras, Sebastian Arlt. Venice: European Veterinary Society for Small Animal Reproduction (EVAR).

Smoliak, D. (2019). Zminy tsytolohichnoho skladu ta stan lokalnoho imunitetu reproduktyvnykh orhaniv sobak v rizni periody estralnoho tsyklu. Redaktsiina kolehiia, 351 (in Ukrainian).

Van den Berghe, F., Paris, D. P. P. B., Sarnyai, Z., Ganswindt, A., \& Paris, M. C. J. (2019). Periovulatory changes in behavior and fecal estrogen and progestogen metabolite concentrations could predict female African wild dogs (Lycaon pictus). In: [Presented at the 7th Conference of the International Society of Wildlife Endocrinology]. From: ISWE 2019: 7th Conference of the International Society of Wildlife Endocrinology, 13-16 October 2019, Kruger National Park, South Africa. URL: https://researchonline.jcu.edu.au/59826.

Van Haaften, B., Bevers, M. M., Van den Brom, W. E., Okkens, A. C., Van Sluijs, F. J., Willemse, A. H., \& Dieleman, S. J. (1994). Increasing sensitivity of the pituitary to GnRH from early to late anoestrus in the beagle bitch. Reproduction, 101(1), 221-225. doi: 10.1530/jrf.0.1010221.

Volkmann, D. H., Kutzler, M. A., Wheeler, R., \& Krekeler, N. (2006). The use of deslorelin implants for the synchronization of estrous in diestrous bitches. Theriogenology, 66(6-7), 14971501. doi: 10.1016/j.theriogenology.2006.01.033.

Volkmann, D. H., Kutzler, M. A., Wheeler, R., Krekeler, N., Klewitz, J., \& Lamb, S. V. (2006). Failure of hCG to support luteal function in bitches after estrus induction using deslorelin implants. Theriogenology, 66(6-7), 1502-1506. doi: 10.1016/j.theriogenology.2006.01.045.

Walter, B., Otzdorff, C., Brugger, N., \& Braun, J. (2011). Estrus induction in Beagle bitches with the GnRH-agonist implant containing $4.7 \mathrm{mg}$ Deslorelin. Theriogenology, 75(6), 11251129. doi: $10.1016 /$ j.theriogenology.2010.11.022.

West, N. B., Verhage, H. G., \& Brenner, R. M. (1976). Suppression of the estradiol receptor system by progesterone in the oviduct and uterus of the cat. Endocrinology, 99(4), 1010-1016. doi: 10.1210/endo-99-4-1010.

Wildt, D. E., Chakraborty, P. K., Panko, W. B., \& Seager, S. W. J. (1978). Relationship of reproductive behavior, serum luteinizing hormone, and time of ovulation in the bitch. Biology of Reproduction, 18(4), 561-570. doi: 10.1095/biolreprod18.4.561.

Yablons'kyy, V. A., \& Khomin, S. P. (2006). Veterynarne akusherstvo, hinekolohiya ta biotekhnolohiya vidtvorennya tvaryn z osnov androlohiyi: Navchal'nyy posibnyk dlya VNZ II-IV r. a. Nova Knyha (in Ukrainian). 